\title{
The Effect of Intermittent Positive Pressure Breathing and Voluntary Hyperventilation upon the Distribution of Ven- tilation and Pulmonary Blood Flow to the Lung in Chronic Obstructive Lung Disease*
}

\author{
George E. Emmanuel, $\dagger$ William M. Smith, and William A. Briscof \\ (From the Cardiopulmonary Laboratory and Chest Service, Columbia University Division, Bellevue Hospital, \\ New York, and the Department of Medicine, State University of New York Downstate Medical \\ Center, Brooklyn, N. Y.)
}

Intermittent positive pressure breathing (IPPB) from an apparatus applying positive pressure to the mouth during inspiration is widely used in the treatment of obstructive lung disease. The literature has recently been well reviewed by Sheldon (1). There was early concern with its effects in decreasing cardiac output $(2,3)$, which are avoided by using equipment that gives a type III mask pressure curve and hence letting the positive pressure phase, i.e., inspiration, occur at a high flow rate and occupy only a small fraction of the respiratory cycle, expiration being prolonged and against zero mask pressure. This type of pressure curve is obtained with machines in current use.

There have been many therapeutic successes following the use of IPPB in severe respiratory failure (1). Its value, however, is debated by some. For example, Sukumalchantra, Park, and Williams maintain that in patients in acute ventilatory failure it frequently fails to lower the arterial carbon dioxide tension (4). Most authors maintain that it is only useful, or is more useful, when given with bronchodilators (5-7). Some maintain that it is not only useless $(5,7)$ but actually harmful (5) to administer oxygen by this method, in that arterial $\mathrm{CO}_{2}$ rises during such treatment. Most workers, however, have found that arterial $\mathrm{CO}_{2}$ falls during IPPB both when air (8) or $\mathrm{O}_{2}(9)$ is given.

* Submitted for publication April 14, 1965; accepted April 13, 1966.

This study was supported in part by research grants HE 02001-10 and HE 5757 from the National Institutes of Health and U-1067 and U-1361 from the Health Research Council of the City of New York.

† Address requests for reprints to Dr. George E. Emmanuel, State University of New York, Downstate Medical Center, Brooklyn, N. Y. 11203.
In reviewing this literature, one is impressed by the fact that most authors, in an effort to obtain the maximal therapeutic effect on blood gases, used a variety of agents in addition to IPPB, such as $\mathrm{O}_{2}$, bronchodilators, wetting agents, and antibiotics $(10,11)$. Furthermore, the tests were performed in patients with widely different degrees of incapacity and with varying relations to the time of application of IPPB, some tests being done immediately after a single treatment (7), others after a course of treatments lasting several weeks (10). Two studies in recent years added greatly to our knowledge of the mechanism by which it produces its effects. Torres, Lyons, and Emerson (12) have found that the least ventilated spaces in the lungs are better ventilated during IPPB. Cohen, Hemingway, and Hemingway (13) have demonstrated conclusively that IPPB has more effect in increasing ventilation and improving its distribution when administered with isoproterenol. However, there seems to be no study in which changes in ventilation and its distribution have been quantitatively related to changes in blood gases and in ventilation-perfusion ( $\left.\dot{\mathrm{V}}_{\mathrm{A}} / \dot{\mathbf{Q}}_{\mathrm{Q}} \mathrm{c}\right)$ ratios.

In the present study, an effort has been made to simplify some of the issues involved and to present a coordinated assessment of changes in both ventilation and blood gases. It is concerned only with the various interrelated physiological phenomena that occur in emphysematous patients during 15- to 20-minute periods of IPPB, not with long term effects. The physiological entities with which we are concerned are 1) total ventilation, 2) distribution of ventilation, 3) distribution of perfusion and of $\dot{\mathrm{V}}_{\mathrm{A}} / \dot{Q}_{\mathrm{Q}} \mathrm{c}$ ratios, 4) 
oxygen consumption of the body, and 5) the effects of these on arterial blood gases. Separate studies were made with air and $\mathrm{O}_{2}$ as the inspired gas. The effects of IPPB were compared with the resting state and with voluntary hyperventilation $(\mathrm{VH})$ as control situations. Accessory factors such as bronchodilators were excluded in order to assess the effects of IPPB alone.

\section{Methods}

Selection of patients. The subjects were patients with chronic respiratory insufficiency recovering from a superimposed episode of acute respiratory failure that had caused their admission to the hospital. They were selected for study because they were well enough to walk or be brought in a wheelchair to the laboratory, unusually cooperative, and most likely to persist in training in $\mathrm{VH}$, which few severely disabled patients are able to maintain for 16 minutes. They presented clinical and radiological evidence of severe chronic pulmonary emphysema, chronic bronchitis, or both, and were receiving regular treatment consisting of IPPB, bronchodilators, and in some patients, antibiotics. Three (A.F., W.W., and M.O.) were receiving digitalis for treatment of cor pulmonale. All had had routine lung function studies including lung volume determination and arterial blood gas analysis, which had shown arterial oxygen unsaturation and carbon dioxide retention during the preceding acute episode. W.W. had a higher maximal breathing capacity than the other patients. $\mathrm{He}$ was a bronchitic, with heart failure due to cor pulmonale during acute exacerbations of bronchitis. His chest $\mathrm{X}$ rays and Gough section of lung at autopsy have been published, as have X-ray findings on A.F. (14).

Procedure. Patients were previously rehearsed to familiarize them with the equipment and train them in the procedures, especially in VH. Six studies were carried out on most patients while they were breathing ambient air and $\mathrm{O}_{2}$ administered in each of three states: at rest, during IPPB, and during VH. During ambient air breathing the minute ventilation $(\dot{V} E)$, arterial $\mathrm{O}_{2}$ saturation $(\mathrm{Sa})$, and arterial $\mathrm{CO}_{2}$ tension $\left(\mathrm{PaCO}_{2}\right)$ were measured in each of the three states. During $\mathrm{O}_{2}$ breathing minute ventilation, the nitrogen washout curve, and the arterial blood gases were measured in each state. Arterial blood samples were taken in all patients at the end of 15 to 20 minutes just before the end of the study. The studies on each subject occupied two or three mornings. They were done in the sitting position with back supported.

Between studies, a resting period of 1 hour permitted the return of the blood gases to the resting state during air breathing. This was confirmed by drawing a sample of arterial blood for analysis before starting the next study. The order used in the present description was not necessarily followed. However, studies during IPPB always preceded studies during VH. The same sheet of paper was used on the recording Tissot spirometer, and during the latter study patients were urged to match their ventilation against the record of the previous IPPB study. The Bird respirator was used without bronchodilators and with an inspiratory pressure of $12 \mathrm{~cm} \mathrm{H}_{2} \mathrm{O}$ in the IPPB studies.

It was impractical in most studies for the subject to be in a steady state of IPPB or VH before being switched to $\mathrm{O}_{2}$ breathing for measurement of the functional residual capacity and $\mathrm{N}_{2}$ washout in the same ventilatory state. In the studies recorded in Tables II and III VH or IPPB began at the same breath as did $\mathrm{O}_{2}$ breathing. These are designated 15-minute studies. However, in studies performed on four patients, recorded in Table IV and designated 30-minute studies, the subjects were switched to breathing $\mathrm{O}_{2}$ for 15 minutes after they had reached a steady state while breathing air for 15 minutes. This necessitated the use of two IPPB machines, one for air and one for oxygen.

Arterial blood gases were analyzed by the Van Slyke method and expired $\mathrm{O}_{2}$ and $\mathrm{CO}_{2}$ during air breathing by the Scholander method. The $\mathrm{N}_{2}$ washout curve was followed by the "two-balloon" procedure, the expired volume and the $\mathrm{N}_{2}$ concentration being measured in $\frac{1}{2}$-minute collections of mixed expired air during a 15-minute or longer period of $\mathrm{O}_{2}$ breathing (15). Allowance is made for $\mathrm{N}_{2}$ eliminated from tissues each $\frac{1}{2}$ minute. This method eliminates the uncertainties and assumptions inherent in the interpretation of end tidal gas samples. It permits assessment of the total quantity of $\mathrm{N}_{2}$ that would be eliminated from the lungs, excluding tissue $\mathrm{N}_{2}$, in an infinitely long period of $\mathrm{O}_{2}$ breathing and gives values for the functional residual capacity $\left(\mathrm{L}_{\mathrm{T}}\right)$ comparable to those obtained with the body plethysmograph (16). It also gives the most reliable assessment of that quantity of $\mathrm{N}_{2}$ which is very slowly eliminated during $\mathrm{O}_{2}$ breathing in obstructive disease of the lungs. It thus delineates the behavior of the slow space, a term coined by Hickam, Blair, and Frayser (17) to refer to a group of very poorly ventilated alveoli or other lung spaces that dominate the behavior of such lungs. Though such spaces are probably scattered throughout both lungs, the singular word "space" is used because they behave as one unit, apparently all having the same ventilation per unit volume (18-21). From the twoballoon $\mathrm{N}_{2}$ washout technique, it is possible to make reliable estimates of the volume $\left(\mathrm{L}_{3}\right)$ and the alveolar ventilation $\left(\dot{\mathrm{V}}_{\mathrm{A}_{3}}\right)$ and of the turnover rate $\left(\dot{\mathrm{V}}_{\mathrm{A}_{3}} / \mathrm{L}_{3}\right)$ in the slow space (15). When arterial $\mathrm{O}_{2}$ saturation, total $\mathrm{O}_{2}$ consumption, total ventilation, and the volume and ventilation of the slow space are known, then 1 ) the fractional perfusion of the slow space (i.e., the maximal fraction of the cardiac output that may perfuse the slow space and be compatible with the observed saturation), and 2) the minimal value of its ventilation-perfusion ratio $\left(\dot{\mathrm{V}}_{3} /\right.$ $\dot{Q} c_{3}$ ) can be determined from the logarithmic graph previously published (22).

The symbols used here are based on those in general use with minor modifications: $\mathrm{L}$ refers to alveolar volume plus dead space or to subdivisions of this in variously ventilated spaces. $L_{T}$ is the functional residual capacity (FRC). The three subscripts $1-2,3$, and $T$ refer, respectively, to collective values in fast spaces, to those in the slow space, and to the total value in all spaces (22). 


\section{Results}

\section{5-minute studies with arterial blood gases}

Ten patients were studied, and the results are given in Tables I, II, and III. Two sets of averages are given. One, referred to subsequently in the text, is the average of all measurements on all subjects including results in those who were not studied in all three states; the other is the average in the five patients in whom all studies were successfully performed. These means, depicted in Figures 1, 2, and 3, have the advantage of presenting and pictorially illustrating more complete studies on fewer patients. Both sets of mean values show the same trends.

a) Ambient air breathing (Table II). Ten patients were studied at rest and during IPPB and eight during voluntary hyperventilation.

Minute ventilation averaged $10.55 \mathrm{~L}$ per minute (range, 8.35 to 13.50 ) at rest, $17.86 \mathrm{~L}$ per minute (range, 12.54 to 25.33 ) during IPPB, and $15.80 \mathrm{~L}$ per minute (range, 11.1 to 24.9) during VH. Thus, these patients were hyperventilating even at rest. Two of these patients (O.N. and R.A.) were able to surpass by voluntary effort for 15 minutes the ventilation achieved during IPPB. Two others (A.F. and J.C.), despite preliminary training, were unable to sustain an adequate degree of $\mathrm{VH}$ for more than a few minutes and so had to be excluded from these studies. In one of these two, A.F., the ventilation achieved during IPPB $(14.1 \mathrm{~L}$ per minute, Table II) was close to his maximal breathing capacity of $16 \mathrm{~L}$ per minute, and it is therefore not surprising that he was unable, without me- chanical aid, to match this performance for 15 minutes.

Oxygen consumption $\left(\mathrm{Vo}_{2}\right)$ averaged $249 \mathrm{ml}$ per minute (range, 199 to 296) at rest, $261 \mathrm{ml}$ per minute (range, 219 to 344 ) after about $15 \mathrm{~min}$ utes of IPPB, and $302 \mathrm{ml}$ per minute (range, 248 to 353 ) after 15 minutes of $\mathrm{VH}$.

Respiratory quotient averaged 0.88 (range, 0.83 to 0.93 ) at rest, 0.96 (range, 0.85 to 1.12 ) after about 15 minutes on IPPB, and 0.94 (range, 8.99 to 1.10 ) on $\mathrm{VH}$.

Arterial $\mathrm{O}_{2}$ saturation averaged $89 \%$ (range, 86 to $91 \%$ ) at rest; on IPPB and VH it rose to mean values of $95 \%$ and $96 \%$, respectively, i.e., the abnormality in the resting saturation is correctable by $\mathrm{VH}$ as well as by IPPB.

Arterial $\mathrm{CO}_{2}$ tension $\left(\mathrm{PaCO}_{2}\right)$ averaged $47 \mathrm{~mm}$ $\mathrm{Hg}$ (range, 40 to 53) at rest, and it fell to the subnormal mean value of $35 \mathrm{~mm} \mathrm{Hg}$ both on IPPB and VH.

The oxygen cost of the extra ventilation $\left(\Delta \dot{\mathrm{V}}_{2} / \Delta \dot{\mathrm{VE}}\right)$ is the ratio between additional $\mathrm{O}_{2}$ consumption above the resting value and the additional ventilation. It averaged $2.2 \mathrm{ml} \mathrm{O}$ and $10.7 \mathrm{ml} \mathrm{O}_{2}$ per $\mathrm{L}$ ventilation on IPPB and $\mathrm{VH}$, respectively.

b) Oxygen breathing: $N_{2}$ washout studies (Table III). These were carried out on nine patients at rest, eight during IPPB, and six during $\mathrm{VH}$.

Minute ventilation averaged $9.8 \mathrm{~L}$ per minute (range, 7.8 to 10.9 ) at rest, $14.6 \mathrm{~L}$ per minute (range, 12.5 to 21.2 ) during IPPB, and $14.0 \mathrm{~L}$ per minute (range, 10.6 to 18.4) during $\mathrm{VH}$. These values were on the whole less than those during air breathing.

TABLE I

Physical characteristics, bellows function, and lung volumes

\begin{tabular}{lccccccc}
\hline \hline & Age & $\begin{array}{c}\text { Body } \\
\text { surface } \\
\text { area }\end{array}$ & $\begin{array}{c}\text { Maximal } \\
\text { breathing } \\
\text { capacity }\end{array}$ & $\begin{array}{c}\text { Vital } \\
\text { capacity }\end{array}$ & $\begin{array}{c}\text { Residual } \\
\text { volume/ } \\
\text { total lung } \\
\text { capacity }\end{array}$ & $\begin{array}{c}\text { Total } \\
\text { lung } \\
\text { capacity }\end{array}$ & $\begin{array}{c}\text { Residual } \\
\text { volume }\end{array}$ \\
\hline Patient & years & $m^{2}$ & $L /$ min & $L$ & $\%$ & $L$ & $L$ \\
J.F. & 48 & 1.65 & 32 & 1.7 & 68 & 4.3 & 2.9 \\
L.F. & 57 & 1.35 & 16 & 2.2 & 70 & 8.5 & 6.0 \\
J.C. & 52 & 1.59 & 19 & 1.1 & 55 & 3.8 & 2.1 \\
W.W. & 65 & 1.46 & 28 & 2.5 & 64 & 6.9 & 4.4 \\
H.V. & 46 & 1.89 & 54 & 3.7 & 54 & 6.9 & 3.7 \\
M.R. & 54 & 1.75 & 23 & 2.5 & 58 & 6.4 & 3.7 \\
R.A. & 65 & 1.70 & 37 & 2.8 & 58 & 6.9 & 4.0 \\
O.N. & 60 & 1.90 & 29 & 2.7 & 52 & 6.4 & 3.3 \\
Mean & 58 & 1.55 & 34 & 2.2 & 68 & 7.3 & 5.0 \\
\hline
\end{tabular}


TABLE II

15-minute studies: air breathing*

\begin{tabular}{|c|c|c|c|c|c|c|c|c|}
\hline Patient & Condition & $\dot{\mathrm{V}}_{\mathbf{E}}$ & f & $\dot{\mathrm{V}}_{\mathrm{AT}}$ & $\dot{\mathrm{V}} \mathrm{O}_{2}$ & $\mathrm{Sa}$ & $\mathrm{PaCO}_{2}$ & $\Delta \dot{V} O_{2} / \Delta \dot{V} E$ \\
\hline J.F. & $\begin{array}{l}\mathrm{R} \\
\mathrm{IPPB} \\
\mathrm{VH}\end{array}$ & $\begin{array}{c}L / \min \\
8.8 \\
15.8 \\
13.9\end{array}$ & $\begin{array}{l}14 \\
16 \\
16\end{array}$ & $\begin{array}{c}L / \min \\
6.0 \\
12.6 \\
10.7\end{array}$ & $\begin{array}{c}\mathrm{ml} / \mathrm{min} \\
293 \\
290 \\
319\end{array}$ & $\begin{array}{l}\% \\
89 \\
95 \\
95\end{array}$ & $\begin{array}{c}\mathrm{mm} \mathrm{Hg} \\
53 \\
37 \\
46\end{array}$ & $\begin{array}{r}m l / L \\
-0.4 \\
+5.1\end{array}$ \\
\hline A.F. & $\begin{array}{l}\text { R } \\
\text { IPPB } \\
\text { VH }\end{array}$ & $\begin{array}{r}9.2 \\
14.1\end{array}$ & $\begin{array}{l}20 \\
16\end{array}$ & $\begin{array}{r}5.2 \\
10.9\end{array}$ & $\begin{array}{l}199 \\
219\end{array}$ & $\begin{array}{l}91 \\
97\end{array}$ & $\begin{array}{l}53 \\
38\end{array}$ & +4.1 \\
\hline L.L. & $\begin{array}{l}\mathrm{R} \\
\text { IPPB } \\
\text { VH }\end{array}$ & $\begin{array}{r}9.9 \\
13.4 \\
11.1\end{array}$ & $\begin{array}{l}19 \\
16 \\
17\end{array}$ & $\begin{array}{r}6.1 \\
10.2 \\
7.7\end{array}$ & $\begin{array}{l}217 \\
221 \\
248\end{array}$ & $\begin{array}{l}90 \\
94\end{array}$ & $\begin{array}{l}49 \\
42\end{array}$ & $\begin{array}{r}+1.1 \\
+25.8\end{array}$ \\
\hline J.C. & $\begin{array}{l}\mathrm{R} \\
\text { IPPB } \\
\text { VH }\end{array}$ & $\begin{array}{l}12.2 \\
16.2\end{array}$ & $\begin{array}{l}24 \\
16\end{array}$ & $\begin{array}{r}7.4 \\
13.0\end{array}$ & $\begin{array}{l}218 \\
227\end{array}$ & $\begin{array}{l}86 \\
89\end{array}$ & $\begin{array}{l}47 \\
44\end{array}$ & +2.3 \\
\hline W.W. & $\begin{array}{l}\mathrm{R} \\
\text { IPPB } \\
\text { VH }\end{array}$ & $\begin{array}{l}11.2 \\
25.3 \\
16.8\end{array}$ & $\begin{array}{l}22 \\
16 \\
16\end{array}$ & $\begin{array}{r}6.8 \\
22.1 \\
13.6\end{array}$ & $\begin{array}{l}266 \\
293 \\
298\end{array}$ & $\begin{array}{l}93 \\
96 \\
96\end{array}$ & $\begin{array}{l}43 \\
26 \\
27\end{array}$ & $\begin{array}{l}+1.9 \\
+5.7\end{array}$ \\
\hline H.V. & $\begin{array}{l}\text { R } \\
\text { IPPB } \\
\text { VH }\end{array}$ & $\begin{array}{r}8.4 \\
12.5 \\
11.4\end{array}$ & $\begin{array}{l}14 \\
12 \\
14\end{array}$ & $\begin{array}{r}5.5 \\
10.1 \\
8.6\end{array}$ & $\begin{array}{l}280 \\
344 \\
329\end{array}$ & $\begin{array}{l}81 \\
98 \\
97\end{array}$ & $\begin{array}{l}54 \\
40 \\
42\end{array}$ & $\begin{array}{r}+15.3 \\
+16.0\end{array}$ \\
\hline N.R. & $\begin{array}{l}\text { R } \\
\text { IPPB } \\
\text { VH }\end{array}$ & $\begin{array}{l}13.4 \\
24.0 \\
18.0\end{array}$ & $\begin{array}{l}24 \\
18 \\
22\end{array}$ & $\begin{array}{r}7.6 \\
20.4 \\
13.6\end{array}$ & $\begin{array}{l}251 \\
266 \\
296\end{array}$ & $\begin{array}{l}90 \\
95 \\
94\end{array}$ & $\begin{array}{l}41 \\
28 \\
31\end{array}$ & $\begin{array}{l}+1.2 \\
+8.0\end{array}$ \\
\hline M.O. & $\begin{array}{l}\text { R } \\
\text { IPPB } \\
\text { VH }\end{array}$ & $\begin{array}{r}8.9 \\
19.0 \\
15.1\end{array}$ & $\begin{array}{l}16 \\
15 \\
18\end{array}$ & $\begin{array}{r}5.7 \\
16.0 \\
11.5\end{array}$ & $\begin{array}{l}242 \\
226 \\
316\end{array}$ & $\begin{array}{l}92 \\
93 \\
94\end{array}$ & $\begin{array}{l}44 \\
30 \\
36\end{array}$ & $\begin{array}{r}-1.6 \\
+11.9\end{array}$ \\
\hline R.A. & $\begin{array}{l}\text { R } \\
\text { IPPB } \\
\text { VH }\end{array}$ & $\begin{array}{l}10.0 \\
13.8 \\
15.2\end{array}$ & $\begin{array}{l}18 \\
12 \\
14\end{array}$ & $\begin{array}{r}6.4 \\
11.4 \\
12.4\end{array}$ & $\begin{array}{l}296 \\
287 \\
353\end{array}$ & $\begin{array}{l}91 \\
96 \\
96\end{array}$ & $\begin{array}{l}40 \\
34 \\
32\end{array}$ & $\begin{array}{r}-2.4 \\
+11.0\end{array}$ \\
\hline O.N. & $\begin{array}{l}\text { R } \\
\text { IPPB } \\
\text { VH }\end{array}$ & $\begin{array}{l}13.5 \\
24.4 \\
24.9\end{array}$ & $\begin{array}{l}24 \\
16 \\
24\end{array}$ & $\begin{array}{r}8.7 \\
21.2 \\
20.1\end{array}$ & $\begin{array}{l}228 \\
232 \\
255\end{array}$ & $\begin{array}{l}88 \\
99 \\
97\end{array}$ & $\begin{array}{l}42 \\
28 \\
32\end{array}$ & $\begin{array}{l}+0.4 \\
+2.37\end{array}$ \\
\hline Mean of all & $\begin{array}{l}\text { R } \\
\text { IPPB } \\
\text { VH }\end{array}$ & $\begin{array}{l}10.6 \\
17.9 \\
15.8\end{array}$ & $\begin{array}{l}20 \\
15 \\
18\end{array}$ & $\begin{array}{r}6.5 \\
14.8 \\
12.3\end{array}$ & $\begin{array}{l}249 \\
261 \\
302\end{array}$ & $\begin{array}{l}89 \\
95 \\
96\end{array}$ & $\begin{array}{l}47 \\
35 \\
35\end{array}$ & $\begin{array}{r}+2.2 \\
+10.7\end{array}$ \\
\hline $\begin{array}{l}\text { Mean of J.F., } \\
\text { W.W., H.V., } \\
\text { N.R., R.A. }\end{array}$ & $\begin{array}{l}\text { R } \\
\text { IPPB } \\
\text { VH }\end{array}$ & $\begin{array}{l}10.1 \\
18.3 \\
15.0\end{array}$ & $\begin{array}{l}18 \\
15 \\
16\end{array}$ & $\begin{array}{r}6.5 \\
15.3 \\
11.8\end{array}$ & $\begin{array}{l}277 \\
296 \\
319\end{array}$ & $\begin{array}{l}89 \\
96 \\
96\end{array}$ & $\begin{array}{l}46 \\
33 \\
36\end{array}$ & $\begin{array}{l}+3.1 \\
+9.2\end{array}$ \\
\hline
\end{tabular}

* Abbreviations: $\mathrm{VE}=$ minute ventilation $; \mathrm{f}=$ respiratory rate; $\dot{\mathrm{V}}_{\mathrm{AT}}=$ total alveolar ventilation; $\dot{\mathrm{V}}_{2}=\mathrm{oxygen}_{2}$ consumption; $\mathrm{Sa}=$ arterial $\mathrm{O}_{2}$ saturation; $\mathrm{Pa}_{\mathrm{CO}_{2}}=$ arterial $\mathrm{CO}_{2}$ tension; $\Delta \dot{\mathrm{VO}}_{2} / \Delta \dot{\mathrm{VE}}=$ extra $\mathrm{O}_{2}$ consumption per liter of extra ventilation; $\mathrm{R}=$ respiratory quotient; IPPB $=$ intermittent positive pressure breathing; and $\mathrm{VH}=$ voluntary hyperventilation.

The arterial $\mathrm{O}_{2}$ saturation rose during $\mathrm{O}_{2}$ breathing to $100 \%$ in all patients. Values over $100 \%$ in Table III reflect an $\mathrm{O}_{2}$ content in excess of the $\mathrm{O}_{2}$ capacity of hemoglobin, due to dissolved $\mathrm{O}_{2}$.

Arterial $\mathrm{CO}_{2}$ tension was $1 \mathrm{~mm} \mathrm{Hg}$ higher (mean, $48 \mathrm{~mm} \mathrm{Hg}$ ) than when breathing air. This change was compatible with the lower minute ventilation while breathing $\mathrm{O}_{2}$. It fell during IPPB and $\mathrm{VH}$, breathing $\mathrm{O}_{2}$, to subnormal levels.

The functional residual capacity averaged $\mathbf{5 . 5}$ $\mathrm{L}$ at rest and 5.4 and $5.3 \mathrm{~L}$ when measured during IPPB and VH, respectively. The volume measured by $\mathrm{N}_{2}$ washout is the gas volume in the lungs at the moment when the patient is switched to $\mathrm{O}_{2}$ breathing, which is the moment when IPPB or $\mathrm{VH}$ begins, both in this and in other studies 
$(12,13)$. In studies where comparable changes in ventilation have occurred, e.g., during exercise, the values measured with the $\mathrm{N}_{2}$ washout beginning after 7 minutes of hyperventilation were less than $10 \%$ greater than those at rest (23-25). To ascertain how much $\mathrm{L}_{\mathrm{T}}$ changes during IPPB, we performed the 30-minute studies described later.

The turnover rate of the slow space $\left(\mathrm{VA}_{3} / \mathrm{L}_{3}\right)$ is the alveolar ventilation in liters per minute per liter of slow space. At rest it averaged 0.200 minute $^{-1}$ (range, 0.117 to 0.450 ), and it increased during IPPB to average 0.316 minute $^{-1}$ (range, 0.140 to 0.880 ). During $\mathrm{VH}$ there was a lesser increase to a mean of 0.245 minute $^{-1}$ (range, 0.258 to 0.364 ). The turnover rates of the fast spaces are high, ranging from 1.4 to 7.4 minutes ${ }^{-1}$ at rest and more during $\mathrm{VH}$ and IPPB. This is about 10 to 40 times greater than the turnover rate in the slow space. Since there is inhomogeneity within the fast spaces, this factor, large as it is, underestimates the high degree of inhomogeneity in these emphysematous lungs.

The alveolar ventilation of the slow space $\left(\mathrm{VA}_{3}\right)$ averaged $721 \mathrm{ml}$ per minute (range, 394 to 1,620 ) at rest. It increased in all but two individuals, L.L. and J.C., during IPPB to a mean of $1,104 \mathrm{ml}$ per minute (range, 399 to 3,170 ). During VH it was virtually unchanged from the resting value, averaging $710 \mathrm{ml}$ per minute (range, 276 to 1,260 ). The alveolar ventilation of the slow space expressed as a percentage of

TABLE III

15-minute studies: measurements made during oxygen breathing and entities derived from them*

\begin{tabular}{|c|c|c|c|c|c|c|c|c|c|c|c|c|c|c|}
\hline Subject & Condition & $\dot{\mathbf{V}}_{\mathbf{E}}$ & f & $\mathrm{Sa}$ & $\mathrm{PaCO}_{2}$ & $\dot{\mathrm{V}}_{\mathbf{A T}}$ & $\dot{\mathrm{V}}_{\mathbf{A}_{3}}$ & $\dot{V}_{A_{3} / L_{3}}$ & $\mathbf{L}_{\mathbf{T}}$ & $\mathrm{L}_{3}$ & $\mathrm{~L}_{3} / \mathrm{L}_{\mathrm{T}}$ & $\dot{\mathrm{V}}_{\mathrm{A}_{3} / \dot{\mathrm{Q}}_{\mathrm{C}_{3}}}$ & $\begin{array}{l}\dot{Q} c_{3} / \\
\dot{Q} c_{T}\end{array}$ & $\frac{\dot{Q}_{c_{3}}}{\dot{Q}_{\mathrm{CT}}} \div \frac{\mathrm{L}_{2}}{L_{T}}$ \\
\hline & & $L / \min$ & & $\%$ & $m m H g$ & $L / \min$ & $\mathrm{ml} / \mathrm{min}$ & $m l / L$ & $L$ & $L$ & $\%$ & & $\%$ & $\%$ \\
\hline \multirow[t]{3}{*}{ J.F. } & $\mathbf{R}$ & 9.7 & 25 & 105 & 58 & 4.7 & 394 & 130 & 4.6 & 3.0 & 65 & 0.160 & 42 & 65 \\
\hline & IPPB & 12.5 & 12 & 106 & 47 & 10.1 & 813 & 324 & 4.4 & 2.5 & 57 & 0.333 & 42 & 74 \\
\hline & VH & 12.2 & 22 & & & 7.8 & 341 & 158 & 4.5 & 2.2 & 48 & 0.222 & 24 & 50 \\
\hline \multirow[t]{2}{*}{ A.F. } & & 9.7 & 21 & 106 & 49 & 5.5 & 582 & 167 & 6.8 & 3.5 & 52 & 0.270 & 54 & 104 \\
\hline & $\begin{array}{l}\text { IPPB } \\
\text { VH }\end{array}$ & 14.0 & 13 & & & 11.4 & 770 & 245 & 6.9 & 3.1 & 46 & 0.475 & 37 & 80 \\
\hline \multirow[t]{2}{*}{ L.L. } & $\mathbf{R}$ & 8.1 & 24 & 102 & 56 & 3.3 & 448 & 117 & 5.0 & 3.8 & 76 & 0.225 & 46 & 61 \\
\hline & $\begin{array}{l}\text { IPPB } \\
\text { VH }\end{array}$ & 13.1 & 22 & & & 8.7 & 399 & 140 & 4.2 & 2.9 & 65 & 0.250 & 36 & 55 \\
\hline \multirow[t]{2}{*}{ J.C. } & $\mathbf{R}$ & 9.9 & 24 & 105 & 53 & 5.1 & 794 & 166 & 5.7 & 4.8 & 24 & 0.268 & 68 & 81 \\
\hline & $\begin{array}{l}\text { IPPB } \\
\text { VH }\end{array}$ & 12.6 & 27 & & & 7.2 & 676 & 180 & 5.7 & 3.8 & 66 & 0.266 & 56 & 85 \\
\hline \multirow[t]{3}{*}{ W.w. } & $\mathbf{R}$ & 10.4 & 20 & 104 & 38 & 6.5 & 1.620 & 450 & 4.3 & 3.6 & 85 & 0.400 & 75 & 88 \\
\hline & IPPB & 17.5 & 14 & 108 & 27 & 14.7 & 3,170 & 880 & 4.3 & 3.6 & 84 & 0.620 & 86 & 102 \\
\hline & VH & 13.9 & 16 & & & 10.7 & 1,260 & 364 & 4.3 & 3.5 & 81 & 0.431 & 49 & 60 \\
\hline \multirow[t]{3}{*}{ H.V. } & $\mathbf{R}$ & 7.8 & 12 & 105 & 49 & 5.4 & 762 & 205 & 5.3 & 3.7 & 70 & 0.209 & 65 & 93 \\
\hline & IPPB & 12.6 & 12 & & & 10.2 & 1,040 & 223 & 5.7 & 4.7 & 82 & 0.658 & 23 & 28 \\
\hline & $\mathrm{VH}$ & 10.9 & 14 & & & 8.1 & 1,020 & 297 & 5.8 & 3.4 & 58 & 0.531 & 34 & 59 \\
\hline \multirow[t]{3}{*}{ N.R. } & $\mathbf{R}$ & 10.9 & 22 & 109 & 35 & 6.8 & 536 & 217 & 4.8 & 2.4 & 51 & 0.222 & 48 & 94 \\
\hline & IPPB & 21.2 & 16 & & 28 & 18.0 & 644 & 224 & 5.3 & 2.8 & 54 & 0.311 & 39 & 72 \\
\hline & VH & 17.7 & 22 & 106 & 30 & 13.8 & 276 & 179 & 5.0 & 1.5 & 31 & 0.172 & 27 & 87 \\
\hline \multirow[t]{2}{*}{ M.O. } & $\begin{array}{l}\mathbf{R} \\
\text { IPPB }\end{array}$ & 10.9 & 18 & 104 & 42 & 7.4 & 452 & 133 & 6.7 & 3.3 & 51 & 0.233 & 40 & 78 \\
\hline & VH & 18.4 & 20 & 102 & 26 & 14.4 & 645 & 197 & 6.9 & 3.2 & 47 & 0.369 & 38 & 81 \\
\hline \multirow[t]{3}{*}{ R.A. } & $\mathbf{R}$ & 11.0 & 24 & & & 6.2 & 897 & 219 & 6.7 & 4.1 & 61 & 0.275 & 55 & 90 \\
\hline & IPPB & 13.2 & 12 & 106 & 32 & 10.8 & 1,320 & 310 & 6.7 & 4.3 & 63 & 0.450 & 51 & 81 \\
\hline & VH & 10.6 & 12 & & & 8.3 & 719 & 277 & 5.4 & 2.5 & 48 & 0.351 & 29 & 60 \\
\hline \multirow[t]{3}{*}{ Mean of all } & $\mathbf{R}$ & 9.8 & 21 & 105 & 48 & 5.7 & 721 & 200 & 5.5 & 3.6 & 66 & 0.251 & 55 & 84 \\
\hline & IPPB & 14.6 & 16 & 107 & 34 & 11.4 & 1,104 & 316 & 5.4 & 3.5 & 65 & 0.420 & 46 & 72 \\
\hline & VH & 14.0 & 18 & 104 & 28 & 10.4 & 710 & 245 & 5.3 & 2.7 & 52 & 0.346 & 34 & 66 \\
\hline \multirow{3}{*}{$\begin{array}{c}\text { Mean of J.F., } \\
\text { W.W., H.V., } \\
\text { N.R., R.A. }\end{array}$} & $\mathbf{R}$ & 10.0 & 21 & 106 & 45 & 5.8 & 842 & 244 & 5.1 & 3.4 & 66 & 0.253 & 57 & 86 \\
\hline & IPPB & 15.4 & 13 & 107 & 33 & 12.7 & 1,397 & 392 & 5.3 & 3.6 & 68 & 0.474 & 48 & 71 \\
\hline & $\mathrm{VH}$ & 13.1 & 17 & 106 & 30 & 9.6 & 723 & 255 & 5.0 & 2.6 & 53 & 0.341 & 32 & 63 \\
\hline
\end{tabular}

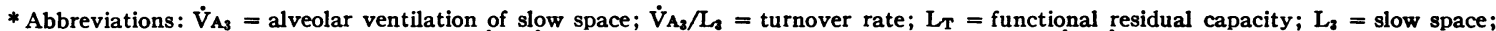
$\mathrm{L}_{3} / \mathrm{L}_{\mathrm{T}}=$ fraction of lung volume in slow space; $\dot{\mathrm{V}}_{\mathrm{A}_{3}} / \dot{Q}_{\mathrm{C}_{3}}=$ ventilation-perfusion ratio in slow space; $\mathbf{Q}_{2} / \hat{Q}_{\mathrm{C}_{T}}=$ percentage of cardiac output perfusing slow space; and $\oint_{c_{2}} / Q_{C T} \div L_{3} / L_{T}=$ index of perfusion of slow space. 


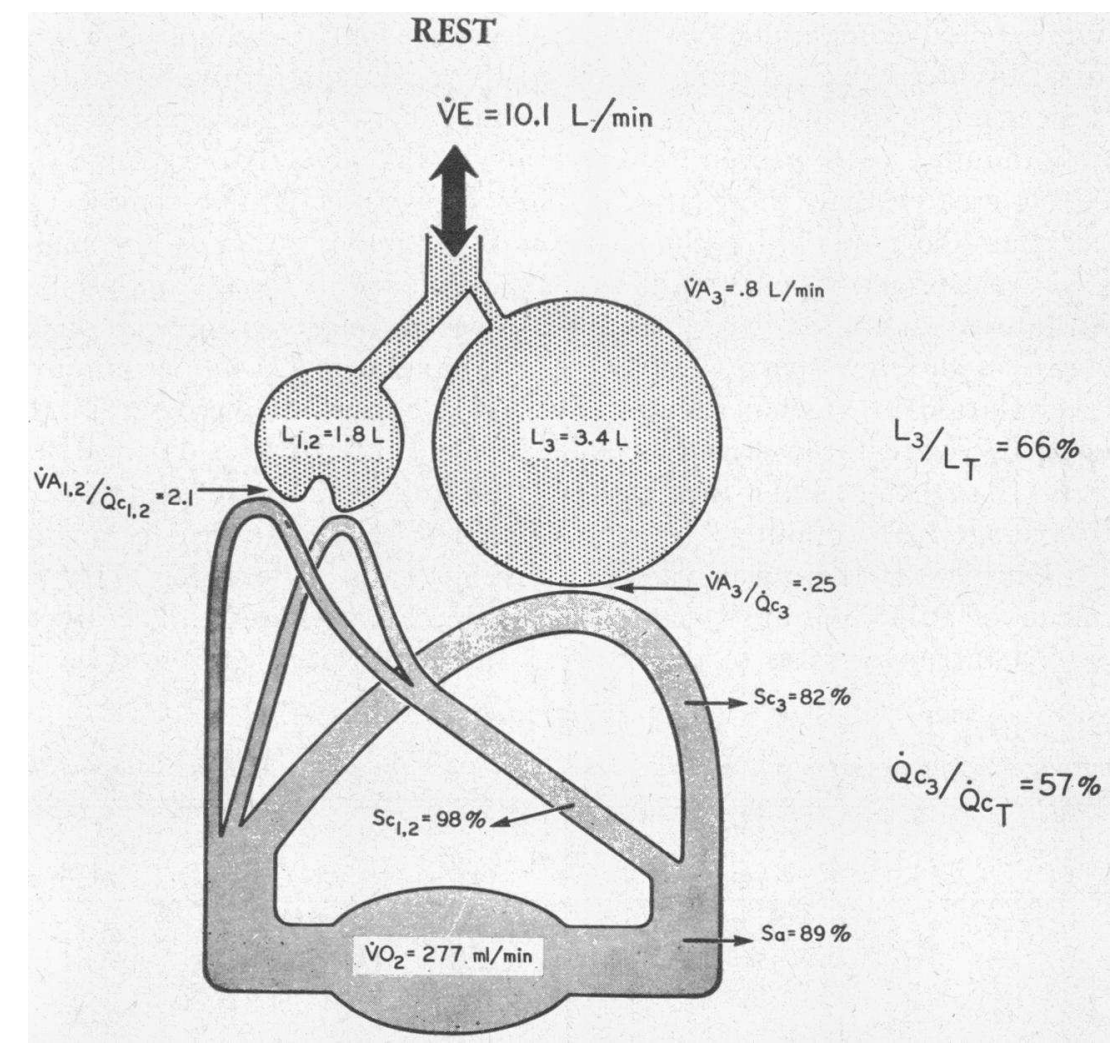

Fig. 1. Diagram of distribution of ventilation and perfusion at rest. Figures 1,2 , and 3 give mean values of five subjects able to complete all studies during voluntary hyperventilation ( $\mathrm{VH}$ ) and intermittent positive pressure breathing (IPPB). The data for minute ventilation $(\dot{V} E)$ and arterial oxygen saturation (Sa) were determined during air breathing, and those for the volume $\left(\mathrm{L}_{3}\right)$ and ventilation $\left(\dot{\mathrm{V}}_{\mathrm{A}_{3}}\right)$ of the slow space were determined during $100 \%$ oxygen breathing. Ventilation and blood flow per minute are indicated by the diameter of the airways and blood vessels and lung volumes by the diameter of the lung spaces. At rest the alveolar ventilation of the slow space is $0.8 \mathrm{~L}$ per minute or $8 \%$ of the minute ventilation. Its volume is $66 \%$ of the functional residual capacity (FRC), and its blood flow is $57 \%$ of the cardiac output. Symbols are as in the text.

total minute ventilation averaged $7.4 \%$ at rest, $7.5 \%$ of the increased minute ventilation during IPPB, and only $5.1 \%$ of the comparable minute ventilation during voluntary hyperventilation. The alveolar ventilation of the fast spaces of these patients constitutes the remainder of the total alveolar ventilation.

The volume of the slow space $\left(\mathrm{L}_{3}\right)$ at rest averaged $3.6 \mathrm{~L}$ (range, 2.4 to 4.8 ) constituting, on the average, $66 \%$ of $\mathrm{L}_{\mathrm{T}}$. It either increased or decreased on IPPB, averaging $3.5 \mathrm{~L}$ (range, 2.5 to 4.7 ) and constituted $65 \%$ of $\mathrm{L}_{\mathrm{T}}$. In $\mathrm{VH}$ there was a consistent tendency for $\mathrm{L}_{3}$ to be reduced to a mean of $2.7 \mathrm{~L}$ (range, 1.50 to 3.5), constituting a smaller percentage $(52 \%)$ of $\mathrm{L}_{\mathrm{T}}$.
The ventilation-perfusion ratio of the slow space $\left(\mathrm{VA}_{3} / \dot{Q}_{3}\right)$ is the minimal value compatible with the data. It averaged 0.25 (range, 0.16 to 0.4 ) at rest, 0.42 (range, 0.25 to 0.66 ) during IPPB, and 0.35 (range, 0.17 to 0.43 ) during VH. The $\dot{V}_{A} / \dot{Q}_{c}$ of the fast spaces as a group averaged 2.37 (range, 1.21 to 3.66) and rose to even higher values during IPPB and VH. A ratio of 1.0 is sufficient to almost fully saturate the blood, i.e., to 97 or $98 \%$.

The fraction of cardiac output perfusing the slow space $\left(\dot{Q}_{\mathrm{c}_{3} /} / \dot{\mathrm{Q}}_{\mathrm{T}}\right)$ is the maximal value compatible with the data. It averaged 0.55 at rest (range, 0.42 to 0.75 ), 0.46 (range, 0.23 to 0.86 ) during IPPB, and during $\mathrm{VH}$ it fell to 0.34 (range, 
0.24 to 0.49 ). These three means for the upper limit of $\dot{Q} c_{3} / \dot{Q} c_{T}$ during rest, IPPB, and VH are, respectively, $0.57,0.48$, and 0.32 , if we consider the data of only those five patients who were studied under all three conditions.

If the lung were evenly perfused in relation to the volume of the slow space, then $\dot{Q} c_{3} / \dot{Q} c_{T}$ should be equal to the fractional volume, $\mathrm{L}_{3} / \mathrm{L}_{\mathrm{T}}$. For instance, the slow space that constitutes $66 \%$ of the FRC at rest would be perfused by $66 \%$ of the cardiac output. However, if this were the case application of the method of analysis previously developed (22) and used here shows that the arterial $\mathrm{O}_{2}$ saturation could not be as high as the observed value (mean, $89 \%$ ) and would instead have to be about $82 \%$.

In the sense that $66 \%$ of the lung is perfused by only $55 \%$ of the cardiac output at rest, the slow space, though overperfused in relation to its ventilation, is underperfused in relation to its volume. The index of perfusion of the slow space relative to its volume $\left(\dot{Q}_{c_{3}} / \dot{Q}_{\mathrm{T}_{\mathrm{T}}}\right) /\left(\mathrm{L}_{3} / \mathrm{L}_{\mathrm{T}}\right)$ had a mean value of 0.84 at rest, 0.72 during $\mathrm{IPPB}$, and 0.66 in $\mathrm{VH}$.

\section{5-minute studies of FRC and distribution of ventilation}

The preceding section reports the effects of $\mathrm{VH}$ and IPPB on arterial blood gases and other entities in studies lasting 15 to 20 minutes, breathing air or $\mathrm{O}_{2}$. However, in other studies designed to assess changes in $L_{T}$ in IPPB and $\mathrm{VH}$ four different but comparable patients hyperventilated air or breathed air from an IPPB machine before being switched to hyperventilating $\mathrm{O}_{2}$ or breathing $\mathrm{O}_{2}$ from a second IPPB machine. Thus, in these studies the patients continuously hyperventilated or were on IPPB without interruption for 30 minutes, during which the inspired gas was changed from air to $\mathrm{O}_{2}$. We are not aware of any previous studies of this type designed to show how much $\mathrm{L}_{\mathrm{T}}$, as measured by prolonged $\mathrm{N}_{2}$ washout in emphysema, changes during IPPB.

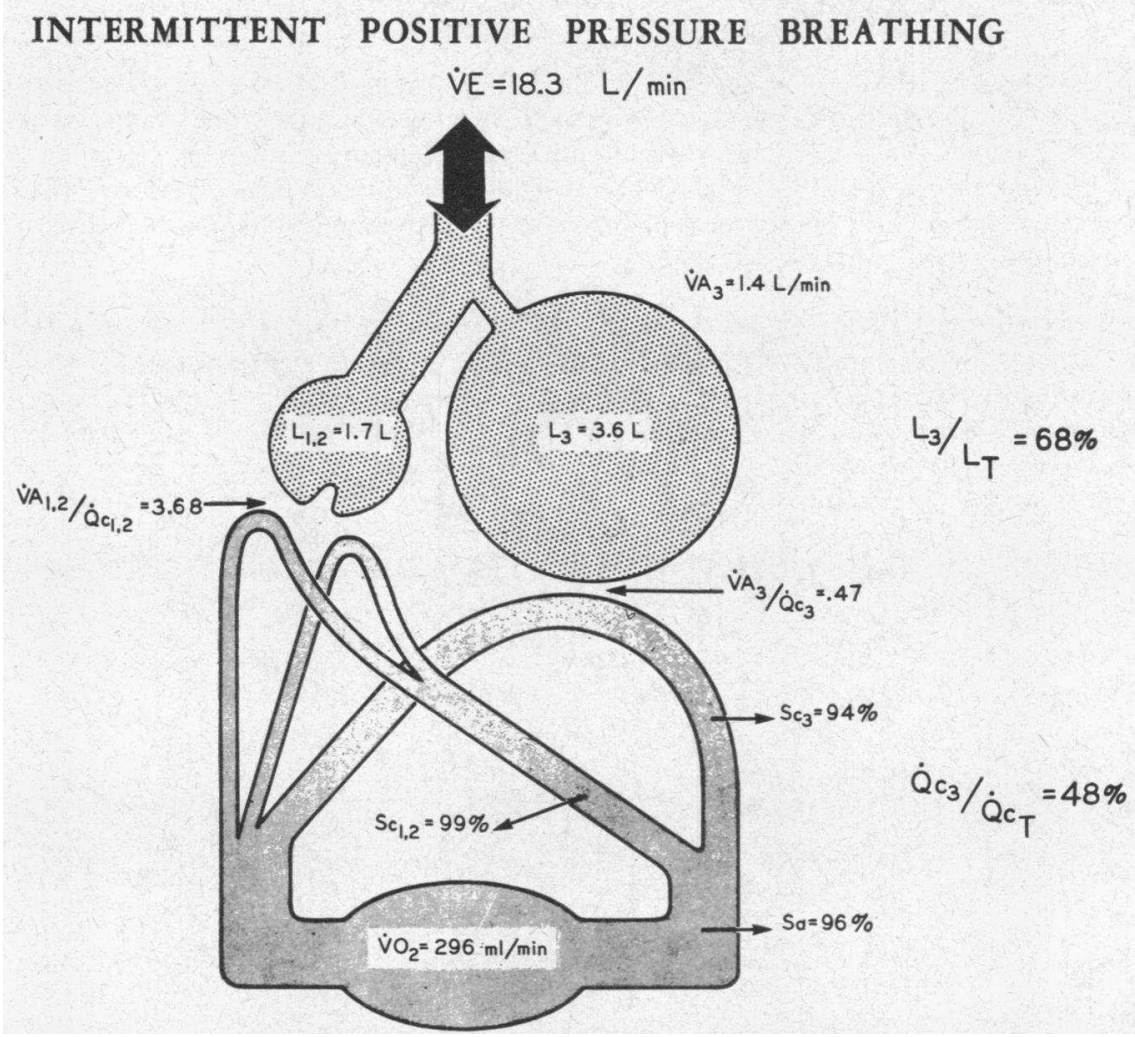

Fig. 2. Distribution of ventilation AND PERfusion DURing IPPB. $\dot{V}_{A_{3}}$ has risen to $1.4 \mathrm{~L}$ per minute, which is $8 \%$ of the minute ventilation. $\mathrm{L}_{3}$ is $68 \%$ of the FRC. Its blood flow has decreased to $48 \%$ of the cardiac output. Symbols are as in the text. 


\section{VOLUNTARY HYPERVENTILATION}

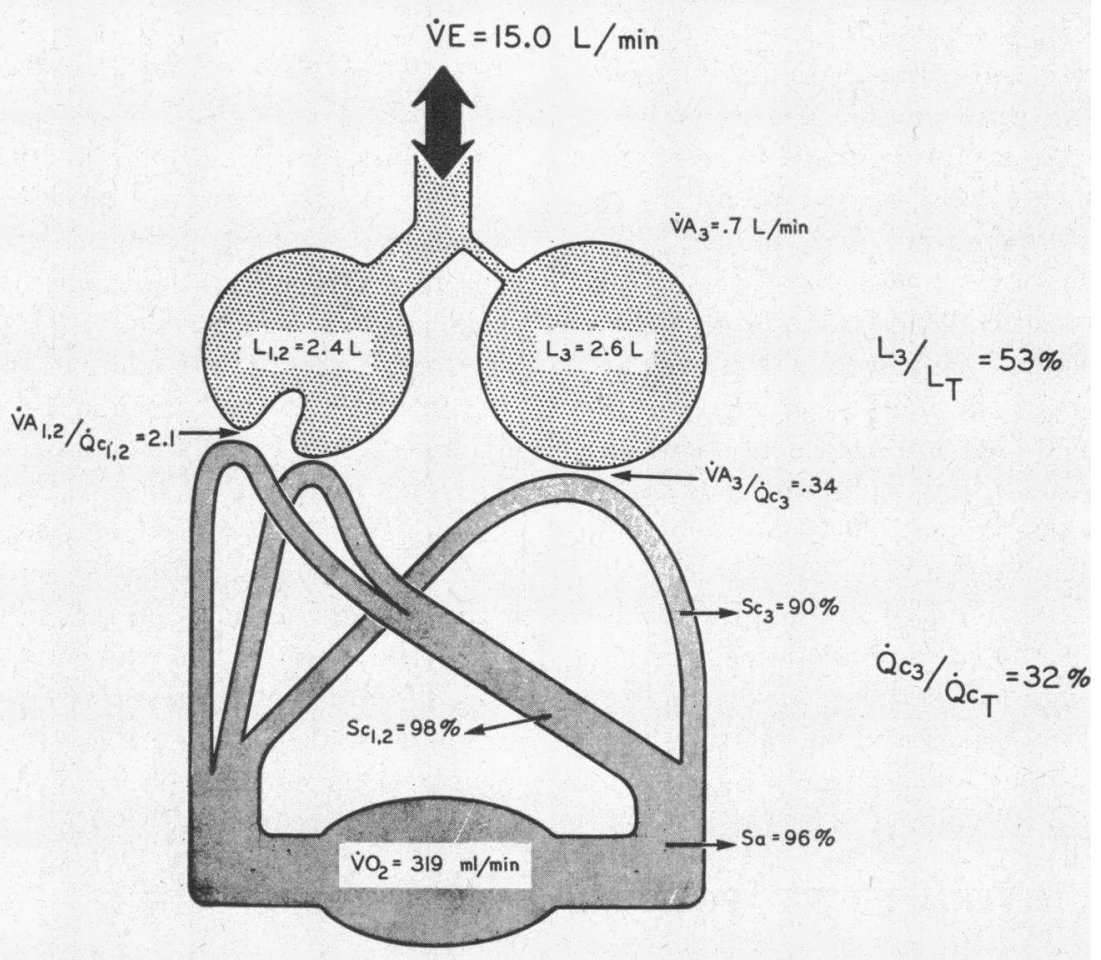

Fig. 3. Distribution OF VENTILATION AND PERFUSION DURING VOLUNTARY hYPERventilation. $\dot{\mathrm{V}}_{\mathrm{A}_{3}}$ is $0.7 \mathrm{~L}$ per minute or $5 \%$ of the minute ventilation. $\mathrm{L}_{3}$ is $2.6 \mathrm{~L}$, which corresponds to $53 \%$ of the FRC. It is lower than the volume of the slow space at rest by $0.8 \mathrm{~L}$. The blood flow to this space has further decreased to $32 \%$ of the cardiac output. Symbols are as in the text.

TABLE IV

25-minute studies of changes in FRC and in distribution of ventilation*

\begin{tabular}{|c|c|c|c|c|c|c|c|c|}
\hline Subject & Condition & $\dot{\mathrm{V}} \mathrm{E}$ & f & $\dot{\mathrm{V}}_{\mathbf{A T}}$ & $\dot{\mathrm{V}}_{\mathrm{A}_{3}}$ & $\mathbf{L}_{\mathbf{T}}$ & $\mathrm{L}_{3}$ & $\mathrm{~L}_{3} / \mathrm{L}_{\mathrm{T}}$ \\
\hline \multirow{3}{*}{ A.S. } & \multirow{3}{*}{$\begin{array}{l}\mathrm{R} \\
\mathrm{IPPB} \\
\mathrm{VH}\end{array}$} & $L / \min$ & & $L / \min$ & $m l / m i n$ & $L$ & $L$ & $\%$ \\
\hline & & 8.9 & 23 & 5.3 & 460 & 4.2 & 2.6 & 61 \\
\hline & & 20.6 & 28 & 16.2 & 568 & 4.4 & 1.8 & 40 \\
\hline J.G. & $\begin{array}{l}\mathrm{R} \\
\text { IPPB } \\
\text { VH }\end{array}$ & $\begin{array}{l}10.0 \\
12.5 \\
14.3\end{array}$ & $\begin{array}{l}20 \\
16 \\
32\end{array}$ & $\begin{array}{r}7.6 \\
10.6 \\
10.3\end{array}$ & $\begin{array}{l}1,430 \\
1,473 \\
1,639\end{array}$ & $\begin{array}{l}8.4 \\
8.4 \\
9.3\end{array}$ & $\begin{array}{l}7.6 \\
7.3 \\
7.9\end{array}$ & $\begin{array}{l}92 \\
87 \\
85\end{array}$ \\
\hline J.C. & $\begin{array}{l}\text { R } \\
\text { IPPB } \\
\text { VH }\end{array}$ & $\begin{array}{l}11.6 \\
14.1\end{array}$ & $\begin{array}{l}18 \\
13\end{array}$ & $\begin{array}{r}9.1 \\
12.3\end{array}$ & $\begin{array}{r}972 \\
1,900\end{array}$ & $\begin{array}{l}4.8 \\
5.6\end{array}$ & $\begin{array}{l}2.9 \\
4.3\end{array}$ & $\begin{array}{l}59 \\
76\end{array}$ \\
\hline E.P. & $\begin{array}{l}\text { R } \\
\text { IPPB } \\
\text { VH }\end{array}$ & $\begin{array}{r}8.3 \\
12.7 \\
8.6\end{array}$ & $\begin{array}{l}20 \\
20 \\
26\end{array}$ & $\begin{array}{r}6.2 \\
10.6 \\
6.0\end{array}$ & $\begin{array}{l}342 \\
380 \\
528\end{array}$ & $\begin{array}{l}4.8 \\
4.9 \\
4.5\end{array}$ & $\begin{array}{l}2.7 \\
2.7 \\
3.2\end{array}$ & $\begin{array}{l}67 \\
55 \\
72\end{array}$ \\
\hline \multirow[t]{2}{*}{$\begin{array}{l}\text { Mean values } \\
\text { of paired } \\
\text { studies }\end{array}$} & $\begin{array}{l}\mathrm{R} \\
\mathrm{IPPB}\end{array}$ & $\begin{array}{l}10.0 \\
13.1\end{array}$ & $\begin{array}{l}19 \\
16\end{array}$ & $\begin{array}{r}7.6 \\
11.2\end{array}$ & $\begin{array}{r}914 \\
1,251\end{array}$ & $\begin{array}{l}6.0 \\
6.3\end{array}$ & $\begin{array}{l}4.4 \\
4.8\end{array}$ & $\begin{array}{l}69 \\
73\end{array}$ \\
\hline & $\begin{array}{l}\mathrm{R} \\
\mathrm{VH}\end{array}$ & $\begin{array}{r}9.0 \\
14.5\end{array}$ & $\begin{array}{l}21 \\
29\end{array}$ & $\begin{array}{r}6.4 \\
10.8\end{array}$ & $\begin{array}{l}744 \\
911\end{array}$ & $\begin{array}{l}5.8 \\
6.1\end{array}$ & $\begin{array}{l}4.3 \\
4.3\end{array}$ & $\begin{array}{l}70 \\
66\end{array}$ \\
\hline
\end{tabular}

${ }^{*} \mathrm{FRC}=$ functional residual capacity. 
As shown in Table IV, $\mathrm{L}_{\mathrm{T}}$ increased on the average of $0.31 \mathrm{~L}$ during IPPB and by $0.30 \mathrm{~L}$ during $\mathrm{VH}$. The ventilation of the slow space $\left(\dot{\mathrm{V}}_{3}\right)$ increased by $0.37 \mathrm{~L}$ during IPPB and by $0.167 \mathrm{~L}$ during $\mathrm{VH}$. The volume of the slow space $\left(\mathrm{L}_{3}\right)$ increased by $0.341 \mathrm{~L}$ during IPPB and decreased by $0.112 \mathrm{~L}$ during $\mathrm{VH}$.

It is significant that the changes in $\mathrm{L}_{T}, \mathrm{~L}_{3}$, and $\dot{\mathrm{V}}_{\mathrm{A}_{3}}$ between rest and $\mathrm{VH}$ and between rest and IPPB are generally of the same order of magnitude as those already presented, although there is a tendency for the lungs to inflate by a few hundred milliliters during sustained $\mathrm{VH}$ or IPPB.

\section{Discussion}

\section{Results during air breathing}

Effect on blood gases. Both IPPB and VH restored the low resting $(89 \%)$ arterial $\mathrm{O}_{2}$ saturation to a nearly normal mean value ( 95 or $96 \%$ ). Both procedures reduced the high resting $\mathrm{PaCO}_{2}$ $(47 \mathrm{~mm} \mathrm{Hg})$ to a low value $(35 \mathrm{~mm} \mathrm{Hg})$. This change was accomplished in 15 minutes with each procedure while breathing air and without bronchodilators. This considerable reduction in $\mathrm{PaCO}_{2}$ coincided with only a small rise from 0.88 to 0.96 or 0.94 in the respiratory quotient $(R)$ measured by gas collections at the end of the 15-minute period. The smallness of the rise in $\mathrm{R}$ at this time suggests that after 15 minutes these subjects were approaching a steady state. Presumably, $\mathrm{R}$ was higher in the earlier minutes of hyperventilation. The effects of IPPB on the blood gases are greater than some of those published by others where there was, on the whole, a smaller minute ventilation during IPPB $(3,8)$. On the other hand, the average $\mathrm{PCO}_{2}$ in our study, $35 \mathrm{~mm} \mathrm{Hg}$, was less affected by IPPB with a mean ventilation of $17 \mathrm{~L}$ per minute than it was in the patients of Cohen and associates (13). Their average $\mathrm{PCO}_{2}$ fell to $29.9 \mathrm{~mm} \mathrm{Hg}$ during IPPB with a larger minute ventilation, $22 \mathrm{~L}$ per minute administered with isoproterenol. Thus the changes in blood gases reported by different investigators are related to the minute ventilation achieved by their patients.

The work of breathing. These subjects were trained to hyperventilate at three or four previous sessions. An effort was made to match their ventilation during $\mathrm{VH}$ and IPPB by warning them sometimes to breath less during IPPB, which was always performed first, and urging them to breath more if necessary during $\mathrm{VH}$ when this was performed later.

Despite the training several subjects, most of them not described here, were unwilling or unable to voluntarily hyperventilate to an adequate degree for 15 minutes. For this reason some studies had to be abandoned during their performance or discarded later because an adequate increase in ventilation was not achieved.

The measurements of oxygen consumption confirm that VH entails a considerable effort by these patients. The average increase in $\dot{\mathrm{V}}_{2}$ above the resting level was $53 \mathrm{ml}$ per minute during $\mathrm{VH}$ and only $12 \mathrm{ml}$ per minute during IPPB where, on the average, a higher ventilation was achieved. The oxygen cost of the extra ventilation, $\Delta \dot{\mathrm{VO}}_{2} / \Delta \dot{\mathrm{V} E}$, averaged $2.2 \mathrm{ml}$ per $\mathrm{L}$ during IPPB and $10.7 \mathrm{ml}$ per $\mathrm{L}$ during $\mathrm{VH}$. The latter is in good agreement with other data on voluntary hyperventilation in emphysema. For example, recalculation of the data of Fritts, Filler, Fishman, and Cournand (26) shows their average value of $\Delta \dot{\mathrm{VO}}_{2} / \Delta \dot{\mathrm{VE}}$ in emphysematous patients during $\mathrm{VH}$ was $11.2 \mathrm{ml}$ per L. Thus, during IPPB the machine, or rather the potential energy of the compressed gas in the tank, does about three-fourths of the mechanical work necessitated by the extra ventilation. This is the most important advantage of IPPB over $\mathrm{VH}$ as performed here. It enables patients with obstructive disease to remain in a nearly resting state while hyperventilating (27).

Another aspect of oxygen consumption deserves mention. When $\dot{\mathrm{V}}_{\mathrm{A}} / \dot{\mathrm{Q}} \mathrm{c}$ ratios are low, as they are in the slow space in emphysema, then mixed venous saturation has, as shown in Figure 3 of a previous publication (28), a significant influence on end capillary saturation not seen in normal men. Any increase in $\mathrm{Vo}_{2}$ is associated either with a fall in mixed venous saturation or with an increase in cardiac output associated with a decrease in $\dot{V}_{A} / \dot{Q}_{c}$ ratios. It therefore tends to lower arterial $\mathrm{O}_{2}$ saturation in emphysema (22). The greater increase in $\dot{\mathrm{V}}_{2}$ during $\mathrm{VH}$ tends to reduce its effectiveness in raising $\mathrm{O}_{2}$ saturation. The fact that it is as effective in this respect as IPPB in these studies in spite of the increase in $\dot{\mathrm{VO}}_{2}$ is due to other adjustments that will be discussed later. 


\section{Results during $\mathrm{O}_{2}$ breathing}

Lung volume considerations. Since the subjects were switched to $\mathrm{O}_{2}$ breathing at the end of a resting expiration, the functional residual capacity $\left(\mathrm{L}_{\mathrm{T}}\right)$ measured here is that at rest. However, the 30-minute studies, in which the subjects were in a steady state of VH or IPPB before being switched to $\mathrm{O}_{2}$ for measurement of $\mathrm{L}_{\mathrm{T}}$, show that the latter increases by less than $10 \%$ of its resting value during $\mathrm{VH}$ and IPPB at the pressure used here, $12 \mathrm{~cm} \mathrm{H}_{2} \mathrm{O}$. Hence, interpretations based on the lung volumes in Table III are not substantially in error.

It is worthwhile to consider how a change in $\mathrm{L}_{\mathrm{T}}$ during the study would affect the interpretation. If, in the present 15 -minute studies, after the onset of VH or IPPB the fast spaces become more inflated and the volume of the slow space is unchanged, then this makes no difference to our interpretations with reference to distribution of ventilation and perfusion; these are largely independent of changes in these alveoli, which fully saturate their perfusing blood. If, however, $\mathrm{L}_{3}$ increased at the onset of VH or IPPB by $10 \%$ above the values given in Table III, then the value derived for the ventilation of the slow space, $\dot{\mathrm{V}}_{\mathrm{A}_{3}}$, would also be increased by $10 \%$. This is so because the turnover rate, $\dot{\mathrm{V}}_{\mathrm{A}_{3}} / \mathrm{L}_{3}$ measured during the study is valid irrespective of these volume changes at the beginning of the study. In that case in a typical study the value derived for fractional perfusion of the slow space, $\dot{\mathrm{Q}} \mathrm{c}_{3} / \dot{\mathrm{Q}}_{\mathrm{T}}$, would increase from 0.57 to 0.59 and that for its ventilation-perfusion ratio, $\dot{\mathrm{V}}_{\mathrm{A}_{3}} / \dot{\mathrm{Q}}_{3}$, from 0.266 to 0.283 . These are small changes, and they show that in these subjects these derived figures are relatively insensitive to changes in lung volume during the study.

Although it is thought by some that the magnitude of the lung volume is related in some way to gas exchange, the physiological connection is not clear. Indeed, provided an alveolus is patent its effectiveness in gas exchange should be dependent on its $\dot{V}_{A} / \dot{Q} c$ ratio and not on its volume. The large size of the slow space is not directly related to its blood gas exchange, though it is related to its slow $\mathrm{N}_{2}$ washout, depending as this does on the turnover rate, i.e., the ventilation to lung volume ratio.

Turnover rates and their significance. In normal lungs there is a wide variation in ventilation per unit volume even among the less ventilated alveoli; hence the concept of the slow space does not fit the $\mathrm{N}_{2}$ washout data very well. The frequency distribution of turnover rates somewhat resembles a bell-shaped normal frequency distribution curve. In emphysematous lungs, however, no normal or log normal frequency distribution will fit the data. The frequency distribution is very skewed in the sense that there is a high frequency of lung volume units with a very low turnover rate (22). This has also been shown by Gomez, Briscoe, and Cumming, treating total $\mathrm{N}_{2}$ elimination in end tidal gas from both the lungs and the tissues in terms of a continuous distribution of turnover rates (29). Insofar as the washout into balloons of $\mathrm{N}_{2}$ from the least ventilated parts of the emphysematous lung, after subtraction of $\mathrm{N}_{2}$ eliminated by the tissues, behaves within the limits of experimental error like a single exponential function during prolonged studies, the concept of the slow space in this disease is a most realistic and useful simplification.

The turnover rates are the least derived and most certain measurements made in these washout curves. They are not in error whatever the degree of inflation of the lung. The turnover rate of the slow space increased during both IPPB and VH. The former had a much greater effect. This is in agreement with Torres and associates (12). The increase in this ratio was due to an increase in $\dot{\mathrm{V}}_{\mathrm{A}_{3}}$ averaging about $35 \%$. This increase in the ventilation of the slow space during IPPB is a small fraction (about onetenth) of the total increase in alveolar ventilation. Evidently, most of the extra ventilation is wastefully directed to the fast spaces. This is the price that must be paid to increase by only about $0.4 \mathrm{~L}$ per minute the ventilation of the slow space, which constitutes most of the lung. Nevertheless, this small increase is of critical importance in blood gas exchange. The magnitude of the effect of IPPB in raising arterial $\mathrm{O}_{2}$ saturation to normal can be explained by the fact that about $10 \%$ of the extra ventilation is directed to the slow space in our patients. In $\mathrm{VH}$ there is no comparable increase in the ventilation of the slow space as measured here. The rise in arterial oxygen saturation must be 
attributed to other causes that will be discussed later.

Ventilation-perfusion ratios. The arterial blood in these patients with emphysema is a mixture of components that have been oxygenated to very different degrees in variously ventilated alveoli. In the simplified model used here the fast spaces have enough ventilation to fully saturate the perfusing blood, since even if the whole cardiac output perfused them their $\dot{\mathrm{V}}_{\mathrm{A}} / \dot{Q}_{\mathrm{C}}$ ratio would be more than unity. Arterial $\mathrm{O}_{2}$ saturation in these patients is critically dependent on the quantity of the ventilation and perfusion of the slow space. Of these two, change in perfusion has the greater influence, since an increase has two deleterious effects: 1 ) it lowers $\dot{\mathrm{V}}_{\mathrm{A}_{3}} / \dot{\mathrm{Q}}_{\mathrm{c}_{3}}$ and hence the $\mathrm{O}_{2}$ saturation of blood oxygenated in the slow space; and 2) it increases the quantity of unsaturated blood mixed into the arterial stream.

The method used to derive VA/Q்c ratios and the distribution of perfusion is illustrated by considering a patient with a high arterial $\mathrm{O}_{2}$ saturation and also a large and very poorly ventilated slow space. It is evident without calculation that there cannot be much blood perfusion of the slow space when the arterial oxygen saturation is high. When the quantitative relationship among the mixed venous $\mathrm{O}_{2}$ saturation, the $\dot{\mathrm{V}}_{\mathrm{A}} / \dot{Q}_{\mathrm{C}}$ ratio in an alveolus, and the resulting end capillary $\mathrm{O}_{2}$ saturation is taken into account, it is possible to determine an upper limit to the fractional perfusion and a lower limit to the $\dot{\mathrm{V}}_{\mathrm{A}} / \dot{\mathrm{Q}} \mathrm{c}$ ratio of the slow space. These limits are valid even if there are shunts, barriers to diffusion, and inhomogeneity of ventilation or perfusion within the slow space (22). They are in reasonable agreement with estimates of $\dot{V}_{\mathrm{A}} / \dot{Q}_{\mathrm{c}}$ ratios by other methods employing radioactive krypton or dissolved urinary $\mathrm{N}_{2}(30)$. The present study assigns numerical values to the ratio or its minimal value in the slow space that fit the data in each study. They lie in the range between 0.15 and 0.6 where small increases in $\dot{\mathrm{V}}_{\mathrm{A}_{3}} / \dot{\mathrm{Q}}_{\mathrm{c}_{3}}$ effect large increases in the $\mathrm{O}_{2}$ saturation of the blood leaving these alveoli (28). The increase in the alveolar ventilation of the slow space observed in IPPB is by itself practically sufficient to account for the observed rise in arterial $\mathrm{O}_{2}$ saturation. However, in $\mathrm{VH}$, where the rise in $\mathrm{VA}_{3}$ is less marked, the rise in arterial $\mathrm{O}_{2}$ saturation is more than would be expected especially when the rise in oxygen consumption is taken into account. It is therefore necessary to invoke reduction of blood perfusion through the slow space as a contributing cause of the rise in saturation. Although the data indicate that this occurred, they do not define the underlying physiological mechanism.

Distribution of perfusion. The fractional perfusion of the slow space $\left(\dot{Q}_{c_{3}} / \dot{Q}_{c_{T}}\right)$ fell in every patient during $\mathrm{VH}$. The average was reduced by $40 \%$ from 0.55 to 0.34 . Reduction in fractional perfusion in the slow space during $\mathrm{VH}$ is expected since some alveoli, included in the slow space at rest, apparently greatly increase their ventilation and become included among fast spaces. Their perfusion is no longer included in that of the slow space. During IPPB the data in Table III show that in one patient (J.F.) it did not change and in another (W.W.) it rose, whereas in the others it fell to a varying, usually small, degree. It therefore seems there was no consistent change in the fractional perfusion during IPPB.

The index of fractional perfusion in relation to fractional volume $\left[\left(\dot{\mathrm{Q}}_{\mathrm{c}} / \dot{\mathrm{Q}}_{\mathrm{T}}\right) /\left(\mathrm{L}_{3} / \mathrm{L}_{\mathrm{T}}\right)\right]$ permits assessment of perfusion of the slow space when the number of lung units therein changes. It is an approximate measure of blood flow in an average anatomic unit in the slow space. The reduction of this index below unity quantitates the underperfusion of the slow space relative to its volume, which is seen even at rest in these subjects. During VH there was in these particular studies a reduced fractional perfusion per anatomic unit of slow space when the reduced volume of this space was taken into account.

The mechanism by which $\mathrm{VH}$ changes the distribution of perfusion in these studies is not known. It is possible that the different intrapleural pressure profile during $\mathrm{VH}$ improves the distribution of perfusion in a manner that cannot yet be defined. In this context it is of interest that other methods of changing the intrapleural pressure profile may sometimes have the same effect. Jameson, Ferrer, and Harvey (8) found that in one patient whose minute ventilation decreased in a tank respirator, there was a substantial increase in arterial oxygen saturation 
and a decrease in Paco2. We have found, among patients studied in the Drinker respirator, several in whom ventilation decreased, distribution of ventilation did not improve, but in whom arterial oxygen saturation rose and arterial $\mathrm{PCO}_{2}$ fell. In the absence of significant change in respiratory rate in these studies, the results were compatible with the notion that intrapleural pressure changes induced by the tank respirator had improved the distribution of perfusion.

\section{Summary}

Studies were made on 14 patients with chronic obstructive disease of the lungs at rest, during intermittent positive pressure breathing, and during voluntary hyperventilation. Changes in arterial blood gases measured during air breathing are correlated with changes in nitrogen washout curves measured during oxygen breathing.

Both intermittent positive pressure breathing and voluntary hyperventilation had the same effect on arterial blood gases, raising arterial oxygen saturation to a normal value and lowering arterial carbon dioxide tension to a subnormal value.

During both procedures there was an increase in oxygen consumption that was about four times as much per liter of added ventilation during voluntary hyperventilation as it was during intermittent positive pressure breathing.

During intermittent positive pressure breathing about one-tenth of the extra ventilation was directed into the slow space. This was enough to account for the observed rise in arterial oxygen saturation. During voluntary hyperventilation the increase in the ventilation of the slow space was less than one-tenth and was not enough to account for the rise in arterial oxygen saturation. This suggests that during voluntary hyperventilation the rise in arterial oxygen saturation was partly due to a reduced fractional perfusion of the slow space.

\section{References}

1. Sheldon, G. P. Pressure breathing in chronic obstructive lung disease. Medicine (Baltimore) 1963, 42, 197.

2. Cournand, A., M. L. Motley, L. Werko, and D. W. Richards, Jr. Physiological studies of the effects of intermittent positive pressure breathing on the cardiac output in man. Amer. J. Physiol. 1948, $152,162$.
3. Motley, H. L., A. Cournand, L. Werko, D. T. Dresdale, A. Himmelstein, and D. W. Richards. Intermittent positive breathing: a means of administering artificial respiration in man. J. Amer. med. Ass. 1948, 137370.

4. Sukumalchantra, Y., S. S. Park, and M. H. Williams. Effect of intermittent positive pressure breathing in acute ventilatory failure. Amer. Rev. resp. Dis. $1965,92,885$.

5. Wu, N., W. F. Miller, R. Cade, and P. Richburg. Intermittent positive pressure breathing in patients with chronic bronchopulmonary disease. Amer. Rev. Tuberc. 1955, 71, 693.

6. Gordon, B., H. L. Motley, P. A. Theodos, L. P. Lang, and J. Tomashefski. Considerations of the clinical and physiologic factors in the treatment of chronic pulmonary conditions. Dis. Chest 1951, 19, 271.

7. Segal, M. S., A. Salomon, M. J. Dulfano, and T. A. Herschfus. Intermittent positive pressure breathing. New Engl. J. Med. 1954, 250, 225.

8. Jameson, A. G., M. I. Ferrer, and R. M. Harvey. Some effects of mechanical respirators upon respiratory gas exchange and ventilation in chronic pulmonary emphysema. Amer. Rev. resp. Dis. 1959, 80, 510.

9. Fraimow, W., R. T. Cathcart, and E. Goodman. The use of intermittent positive pressure breathing in the prevention of the carbon dioxide natcosis associated with oxygen therapy. Amer. Rev. resp. Dis. $1960,81,815$.

10. Smart, R. H., C. K. Davenport, and G. W. Pearson. Intermittent positive pressure breathing in emphysema of chronic lung diseases. J. Amer. med. Ass. 1952, 150, 1385.

11. Motley, H. L., and J. F. Tomashefski. Effect of high and low $\mathrm{O}_{2}$ levels and intermittent positive pressure breathing on oxygen transport in the lungs in pulmonary fibrosis and emphysema. J. appl. Physiol. 1950, 3, 189.

12. Torres, G., H. A. Lyons, and P. Emerson. Effects of intermittent positive pressure breathing on the intrapulmonary distribution of inspired air. Amer. J. Med. 1960, 29, 946.

13. Cohen. A. A., A. Hemingway, and C. Hemingway The effect of intermittent positive pressure breathing and of bronchodilator drugs on alveolar nitrogen clearance in patients with chronic obstructive pulmonary emphysema. Amer. Rev. resp. Dis. 1961, 83, 340 .

14. Harvey, R. M., and M. I. Ferrer. A clinical consideration of cor pulmonale. Circulation 1960, 21, 236.

15. Emmanuel, G., W. A. Briscoe, and A. Cournand. Method for the determination of the volume of air in the lungs: measurements in chronic pulmonary emphysema. J. clin. Invest. 1961, 40, 329.

16. Tierney, D. F., and J. A. Nadel. Concurrent measurements of functional residual capacity by three methods. J. appl. Physiol. 1962, 17, 871. 
17. Hickam, J. B., E. Blair, and R. Frayser. An opencircuit helium method for measuring functional residual capacity and defective intrapulmonary gas mixing. J. clin. Invest. 1954, 33, 1277.

18. Robertson, J. S., W. E. Siri, and H. B. Jones. Lung ventilation patterns determined by analysis of nitrogen elimination rates; use of the mass spectrometer as a continuous gas analyzer. J. clin. Invest. 1950, 29, 577.

19. Fowler, W. S., H. R. Cornish, Jr., and S. S. Kety. Lung function studies. VIII. Analysis of alveolar ventilation by pulmonary $\mathrm{N}_{2}$ clearance curves. $\mathrm{J}$. clin. Invest. 1952, 31, 40.

20. Briscoe, W. A. Further studies on the intrapulmonary mixing of helium in normal and emphysematous subjects. Clin. Sci. 1952, 11, 45.

21. Briscoe, W. A., and A. Cournand. Uneven ventilation of normal and diseased lungs studied by an opencircuit method. J. appl. Physiol. 1959, 14, 284.

22. Briscoe, W. A., E. M. Cree, J. Filler, H. E. J. Houssay, and $A$. Cournand. Lung volume, alveolar ventilation and perfusion interrelationships in chronic pulmonary emphysema. J. appl. Physiol. 1960, $15,785$.

23. Emmanuel, G., F. Moreno, G. Torres, and H. A. Lyons. Effect of exercise on the distribution of ventilation and blood perfusion to the lung in emphysema. Fed. Proc. 1961, 20, 421.

24. Lusk, W., J. Hickam, S. Bondurant, and R. Frayser. Effect of exercise on intrapulmonary gas mixing in normal subjects and in patients with pulmonary emphysema. Clin. Res. Proc. 1956, 4, 47.

25. Hanson, J. S., B. S. Tabakin, and E. J. Caldwell. Response of lung volumes and ventilation to posture change and upright exercise. J. appl. Physiol. 1962, 17, 783.

26. Fritts, H. W., Jr., J. Filler, A. P. Fishman, and A. Cournand. The efficiency of ventilation during voluntary hyperpnea: studies in normal subjects and in dyspneic patients with either chronic pulmonary emphysema or obesity. J. clin. Invest. 1959, 38, 1339.

27. Ayres, S. M., R. L. Kozam, and D. S. Lukas. Effects of intermittent positive pressure breathing on intrathoracic pressure, pulmonary mechanics and the work of breathing. Amer. Rev. resp. Dis. 1963, 87, 370.

28. Briscoe, W. A. A method for dealing with data concerning uneven ventilation of the lung and its effects on blood gas transfer. J. appl. Physiol. 1959, 14, 291.

29. Gomez, D. M., A. W. Briscoe, and G. Cumming. Continuous distribution of specific tidal volume throughout the lung. J. appl. Physiol. 1964, 19, 683.

30. Briscoe, W. A., and A. Cournand. The degree of variation of blood perfusion and of ventilation within the emphysematous lung and some related considerations in Ciba Symposium on Pulmonary Structure and Function, A. V. S. de Reuck, Ed. London, J. \& A. Churchill, 1962, p. 304. 